\title{
Interleukin 25 Measurement
}

National Cancer Institute

\section{Source}

National Cancer Institute. Interleukin 25 Measurement. NCI Thesaurus. Code C74822.

The determination of the amount of interleukin 25 present in a sample. 